\title{
MANAGEMENT OF CUMULATIVE IMPACTS: LESSONS FROM CANTERBURY, NEW ZEALAND
}

\author{
BRYAN R. JENKINS ${ }^{1}$ \\ University of Adelaide, Australia
}

\begin{abstract}
When sustainability limits for resource use or adverse effects from multiple users are reached, there is a need to manage for the cumulative impacts of all users as well as the impacts of individual users. Irrigation expansion in Canterbury led to sustainability limits for water availability for further irrigation and water quality decline from land use intensification. This paper illustrates some of the key lessons for management of cumulative impacts from Canterbury examples. In the Rakaia-Selwyn Groundwater Zone, the spatial scale of management shifted from managing the drawdown impacts on adjacent bores to managing the total extraction from the groundwater zone and the effects on flows in groundwater-fed streams. The management of nitrate contamination from land use intensification across the Canterbury Plains required analysis of the cumulative effects of current and future developments on drinking water quality: this also led to requirements for increased controls on existing users and raised the issue of affordability of additional controls. As illustrated in water quality management for Lake Benmore, modelling of cumulative effects is more complex than modelling the effects of individual projects. Uncertainties in predicting cumulative effects can be greater than the contributions of individual projects. This creates difficulties not only in setting overall limits for managing cumulative effects but also in determining whether impacts from project proposals can be accommodated. The setting of nitrogen discharge limits on land users in the catchment of Wainono Lagoon demonstrates the issue of equity considerations in allocation of discharge allowances. This is not only for the allocation among existing users but also between existing dischargers and potential new dischargers. The management of salinisation of the Woolston-Heathcote groundwater supply is an example of the need to manage the collective contributions of those responsible for adverse effects not just the individual users. The greater complexity of monitoring for the management of cumulative impacts is illustrated in the management of environmental flows in the Te Ngawai River. This required integrating the measurements of individual extractions and the combined effect on river flow in real time.
\end{abstract}

Keywords: complex models, cumulative effects, equitable allocation, monitoring, sustainability limits, water management.

\section{INTRODUCTION}

A challenge for project-level impact assessment is the management of cumulative effects. This is where the impact of the individual project may be small, but when its impact is added to the impacts of past, present and reasonably foreseeable projects, the combined effects are significant. When sustainability limits are being reached, management of cumulative impacts and the management of a project's environmental effects are needed.

The assessment of the combined effects of the proposed developments, existing developments and foreseeable future developments changes the nature and scope of the impact assessment task. It also changes the identification of measures to resolve the management of effects as well as their implementation. Examples from the Canterbury region are used to illustrate some of the significant issues associated with the management of cumulative impacts. This paper extends an earlier work on challenges in cumulative impact assessment (Jenkins [1]).

The broader spatial effects of cumulative impacts require management at the scale of the cumulative effects which are often greater than the localised impact of an individual project.

${ }^{1}$ Orcid:http://orcid.org/0000-0002-4031-101x 
This is illustrated in the example of groundwater extraction from the Rakaia-Selwyn Groundwater Zone.

Prevention of cumulative effects requires analysis in advance of developments. This means that the analysis may be needed prior to there being proponents of that development. This is evident in the example of nitrate contamination from irrigation expansion for dairying on the Canterbury Plains.

The modelling of cumulative effects is more complex than modelling project effects. Furthermore, the uncertainties associated with cumulative effects modelling are greater, and the extent of uncertainty can be greater than the contribution of individual projects. This creates difficulties not only in setting aggregate limits for managing cumulative effects but also in setting specific controls on individual project contributions. The modelling of cumulative effects of land use intensification on water quality in Lake Benmore is an example of these issues.

The setting of aggregate limits for managing cumulative effects also introduces equity considerations in the allocation of discharge allowance contributions not only among existing users but also between existing dischargers and potential new dischargers. This issue was highlighted in setting nitrogen discharge limits on the land use in the catchment of Wainono Lagoon.

Resolution of cumulative effects requires actions from all contributors to the effects. This contrasts with project-level assessment where conditions are set for controlling the proposed development. The management of the salinisation of the Woolston-Heathcote groundwater supply is an illustration of this issue.

The management of cumulative effects requires integrated monitoring of individual contributions, cumulative effects and environmental capacity. An example of this approach is the management of environmental flows in the Te Ngawai catchment.

\section{SCOPE OF IMPACT MANAGEMENT IN RAKAIA-SELWYN GROUNDWATER ZONE}

The Rakaia-Selwyn Groundwater Zone is an unconfined aquifer that forms part of the Canterbury Plains between the Rakaia River and the Selwyn River (Fig. 1). Recharge is from rainfall and river seepage. There are groundwater-fed lowland streams that discharge into Lake Ellesmere (Te Waihora). There has been a major expansion of dairying that is dependent on irrigation using groundwater.

The initial concern with applications for a new groundwater extraction bore was the drawdown impact on neighbouring bores. Interference effects were to be no more than $20 \%$ of the available drawdown and $80 \%$ of drawdown was to be available at a groundwater level exceeded $80 \%$ of the time during the period of proposed use (Environment Canterbury [2]). However, with the fourfold increase in consents to extract groundwater, there was also a concern with the cumulative effects of lowering the groundwater table in the entire RakaiaSelwyn Groundwater Zone and the reduction of flow in the groundwater-fed lowland streams. These effects were exacerbated in years of low rainfall.

To manage these cumulative effects, groundwater zone allocations were defined to maintain flows in groundwater-fed streams. The concept was based on restricting further consents for groundwater withdrawal when the effective allocation of groundwater exceeded the groundwater zone allocation limit. Groundwater zone allocation limits were defined as $50 \%$ of the average land surface recharge, and the effective allocation of groundwater was established from consented volumes and the type of use (e.g. for irrigation users with limits 


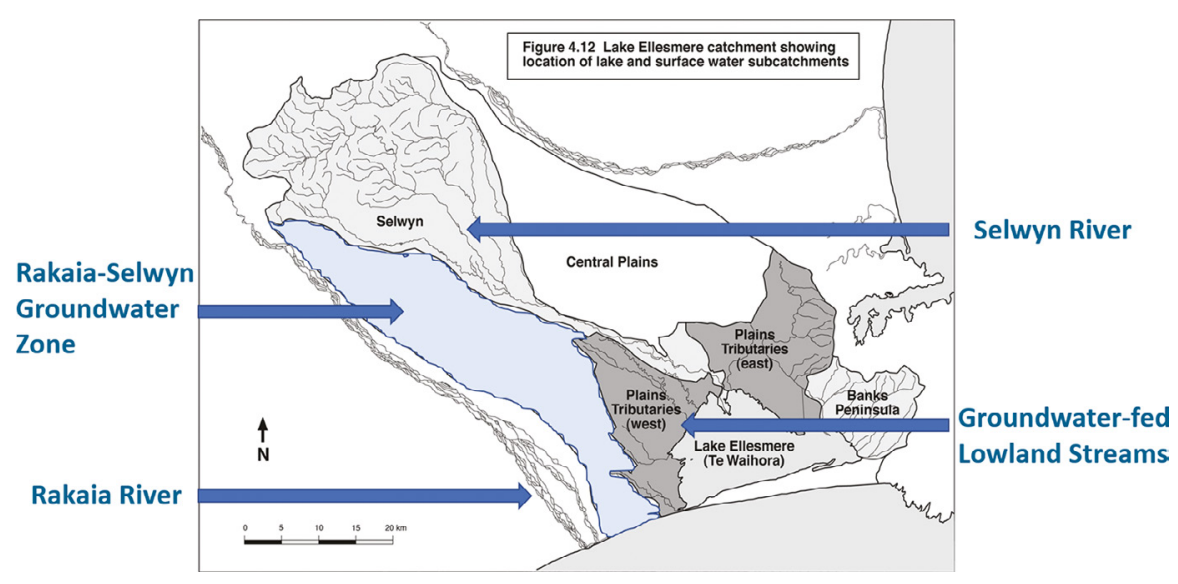

Figure 1: Rakaia-Selwyn Groundwater Zone (Environment Canterbury).

based on daily rate of abstraction, effective allocation was taken as $60 \%$ of the consented rate for an irrigation season of 150 days) (Scott et al. [3]). The policy was that the recommendation to hearing panels for consent applications for further groundwater abstraction would be to decline the consent unless there is information available indicating further taking of water would not result in adverse environmental effects.

The Rakaia-Selwyn Groundwater Zone was the first groundwater zone in Canterbury where allocations reached the groundwater zone allocation limit. However, with strong demand for water, further applications for groundwater withdrawal were received. There is significant inter-annual variability in rainfall recharge which results in variable groundwater levels and lowland stream flows. To protect the maintenance of flows in lowland streams, a trigger level method was introduced to manage cumulative effects in low rainfall/low groundwater/low lowland stream flow years (Environment Canterbury [4]).

The level used to trigger a decision on water availability is the groundwater level at the beginning of the irrigation season (1 September). For water to be available under these new consents in the upcoming irrigation season, the groundwater level on 1 September has to exceed the reserved water level (this was defined as the level at 1 September 2005). The estimated groundwater recession during the coming irrigation season due to extraction and natural decline was not to bring the groundwater level below the environmental safeguard level (this was defined as the level at 30 April 2006).

The groundwater recession for full allocation of the new consent was estimated to be the combination of (1) recession due to natural discharge, referred to as the seasonal environmental discharge and was based on the 2005/6 natural discharge during the irrigation season; (2) the recession due to abstraction drawdown of existing consents, referred to as the seasonal abstractive discharge also based on the 2005/6 irrigation season; and (3) the recession due to the drawdown of the new consent which was calculated as the 150-day drawdown in a virtual bore $750 \mathrm{~m}$ from the new consented bore.

If the groundwater level at the start of the irrigation season (i.e. the trigger level at 1 September) is at or below the reserved water level, then no abstraction is permitted in the upcoming irrigation season. If the trigger level exceeds the reserved water level by more than combined recession, then full allocation is available. For intermediate trigger levels, a pro rata allocation is available. An example calculation is provided in the boxed text. 
Box 1: Application of Trigger Levels to New Consents

(1) Reference parameters based on 2005/6 irrigation season: The reserved water level (spring high water level on 1 September 2005) is $2.18 \mathrm{~m}$ below ground level (BGL) and the environmental safeguard level (autumn low water level on 30 April 2006) is $1.678 \mathrm{~m}$ BGL. The difference between these levels, $0.502 \mathrm{~m}$, is the total groundwater recession (i.e. the sum of the seasonal abstractive discharge and the seasonal environmental discharge). The drawdown of the new consent, calculated as the drawdown at a virtual bore $750 \mathrm{~m}$ from new consented bore resulting from abstracting the consented volume $\left(66,780 \mathrm{~m}^{3}\right) 150$ days, is $0.050 \mathrm{~m}$.

(2) Seasonal assessment for the 2015/6 irrigation season: The trigger level (i.e. the groundwater level at 1 September 2015) is $2.19 \mathrm{~m}$ BGL. This is $0.01 \mathrm{~m}$ in excess of the reserved water level. Thus, the allowable drawdown from the new consent is $0.01 \mathrm{~m}$. This is $19 \%$ of the calculated drawdown for full consented volume. Thus, the water allocation for the $2015 / 6$ irrigation season is $0.19 \times 66,780=12,689 \mathrm{~m}^{3}$.

\section{MANAGEMENT OF CANTERBURY PLAINS NITRATE CONTAMINATION}

Investigations for the Canterbury Water Management Strategy modelled nitrate leaching from existing land use and then assessed nitrate leaching if all potentially irrigable land was irrigated using existing land use practices (Bidwell et al. [5]). The modelling of the existing situation correlated well with field monitoring of nitrates which indicated samples from $11 \%$ of the wells had nitrate concentrations that exceeded the maximum acceptable value for drinking water of $11.3 \mathrm{mg} / \mathrm{L}$ (Environment Canterbury [6]).

The modelling of nitrate leaching if all potentially irrigable land was irrigated at current nitrate leaching rates indicates substantial areas exceeding the drinking water standard (Fig. 2). This means that if further land use intensification is to occur on the Canterbury Plains, then there is a need to improve land use practices to manage nitrate leaching.

As part of the programme for implementing the Canterbury Water Management Strategy, work was undertaken to determine catchment load limits and limits for nitrate leaching for different land uses within catchments (see Wainono Lagoon example below). Furthermore, documentation of land use practices which reduced nitrate leaching rates was identified (FAR et al. [7]).

There has been a willingness among farmers to improve land use practices, even though they have consent approval for their current practices. However, it is evident that there are affordability limits to the investment in improved land use practices by existing farmers. While practice is improving, the level of intervention that is required to sustainable water quality outcomes appears to be greater than what farmers consider affordable (Jenkins [8]).

\section{CUMULATIVE EFFECTS ANALYSIS OF LAKE BENMORE}

In the Mackenzie Basin, irrigation expansion, primarily for converting dryland sheep farms into irrigated dairy farms, was leading to increased nutrients in rivers and lakes in the catchment of Lake Benmore. Concerns about eutrophication in Lake Benmore led to the assessment of the cumulative effects of land use intensification. Lake Benmore is an artificial lake in the Southern Alps and forms part of the Waitaki hydroelectric development. It has two arms (Fig. 3). One is the northern Haldon Arm with a large inflow from the Ohau C Canal 


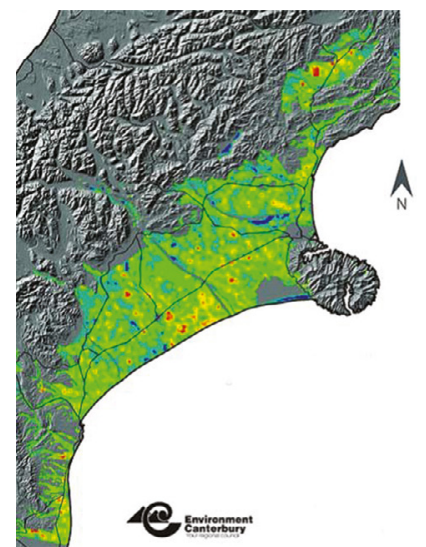

Steady state conditions with existing land use
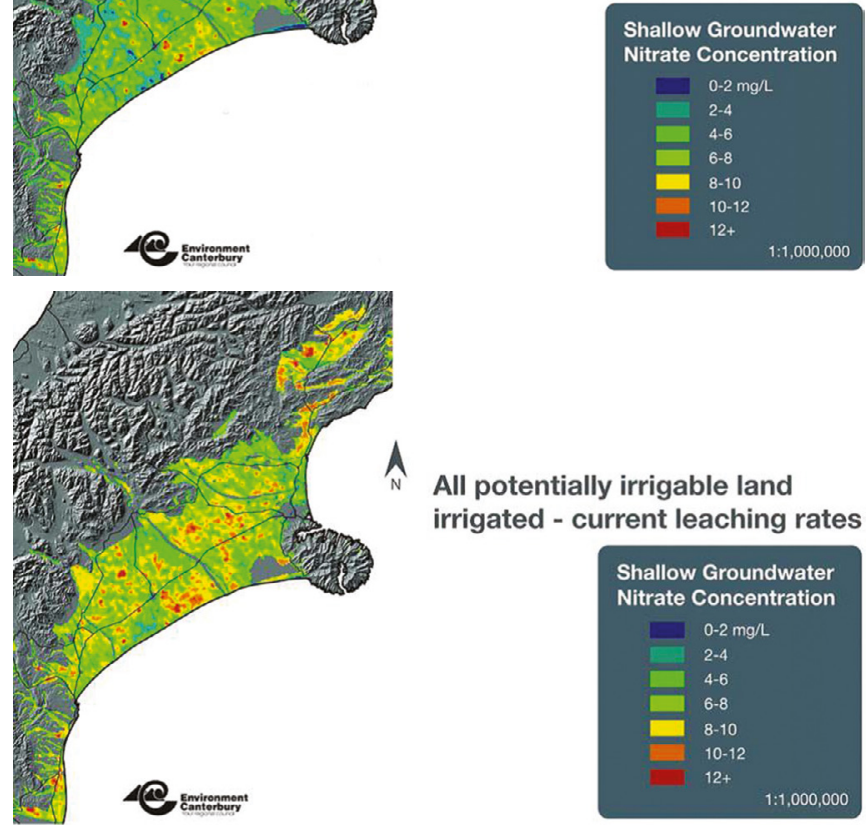

A All potentially irrigable land irrigated - current leaching rates

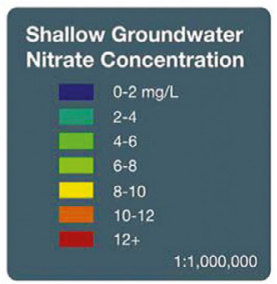

Figure 2: Nitrate modelling in shallow groundwater of the Canterbury Plains (Bidwell et al. [5]).

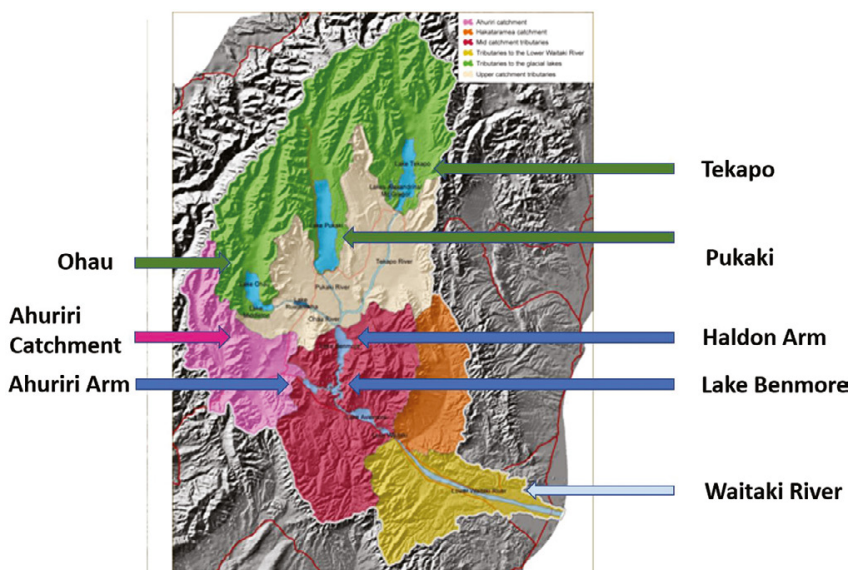

Figure 3: Lake Benmore in the Waitaki Catchment (Environment Canterbury). 
(about $250 \mathrm{~m}^{3} / \mathrm{s}$ annual average flow) fed mainly by glacial catchments (Lake Tekapo, Lake Pukaki and Lake Ohau) that are relatively unaffected by land use intensification. The other is the western Ahuriri Arm with a smaller inflow from the Ahuriri River (about $28 \mathrm{~m}^{3} / \mathrm{s}$ annual average inflow). The Ahuriri Arm is more sensitive to increased nutrients and is susceptible to algal blooms.

An initial modelling study in 2008-2009 (Norton et al. [9]) used computer models that simulate coupled hydrodynamic, water quality and biochemical cycles in aquatic ecosystems that provided three-dimensional predictions of nutrients, temperature, dissolved oxygen and phytoplankton as an input to lake management decision-making. The key management issues were the trophic status of the lake (using the trophic level index (TLI) as a performance measure) and nitrogen loading from catchment land use (this is the main contaminant from conversions to dairy farms). Modelling was being used as a predictive tool to relate the cumulative effects of land use intensification (in terms of nutrient loading) to water quality objectives for Lake Benmore (in terms of TLI criteria). A second round of modelling in 2011-2013 for different catchment scenarios using updated lake inflow data raised questions about the adequacy of model validation. Also, measured in-lake nutrient concentrations were higher than predicted concentrations based on available river flow and nutrient concentrations: this pointed to possible insufficiencies in the input data for nutrient loading (Spigel et al. [10]).

For the more sensitive Ahuriri Arm, the initial assessment in 2008-2009 indicated a current catchment load for total nitrogen of $173 \mathrm{tN} / \mathrm{y}$. The initial modelling predicted that the total nitrogen load for the lake to remain in the oligotrophic range (TLI $=2.9$ ) was $256 \mathrm{tN} / \mathrm{y}$. This implies that there is potential for further intensification in the Ahuriri Catchment. However, the updated modelling in 2012-2013 found that the Ahuriri Catchment load had been underestimated: the revised figure for total nitrogen was $253 \mathrm{tN} / \mathrm{y}$. It was also found that the model was underpredicting nutrient concentrations. This implies that there is no capacity for further intensification in the Ahuriri Catchment if the lake water quality criteria are to be met. (Refer Table 1 and Fig. 4a and 4b.)

Calibration relied on expert judgement by visual comparison of modelled and observed values. As noted by Robson and Hamilton [11], it is not yet feasible to apply statistical fitting or optimisation algorithms to coupled three-dimensional hydrodynamic and biogeochemical models at reasonable resolutions; in practice, complex simulation models are most commonly calibrated by trial and error.

Table 1: Comparison of Modelled and Observed Total Nitrogen Concentrations for the Ahuriri Arm of Lake Benmore (Spigel et al. [10]).

\begin{tabular}{lcc}
\hline & Total Nitrogen $(\mu \mathrm{g} / \mathrm{L})$ & $\begin{array}{l}\text { Trophic Level Index } \\
\text { Total Nitrogen component }\end{array}$ \\
\hline 2008-2009 observed & 132 & 2.77 \\
2008-2009 modelled & 89 & 2.26 \\
& & \\
2011-2012 observed & 119 & 2.63 \\
2012-2013 observed & 248 & 3.60 \\
2011-2013 modelled & 133 & 2.78 \\
\hline
\end{tabular}

Note: Averages over depths for observed results and corresponding model predictions. 


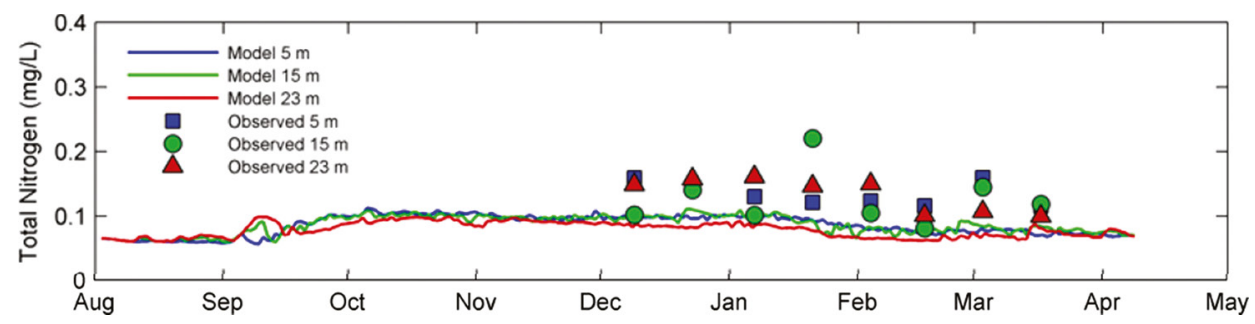

Figure 4a: Results from August 2008 to April 2009.

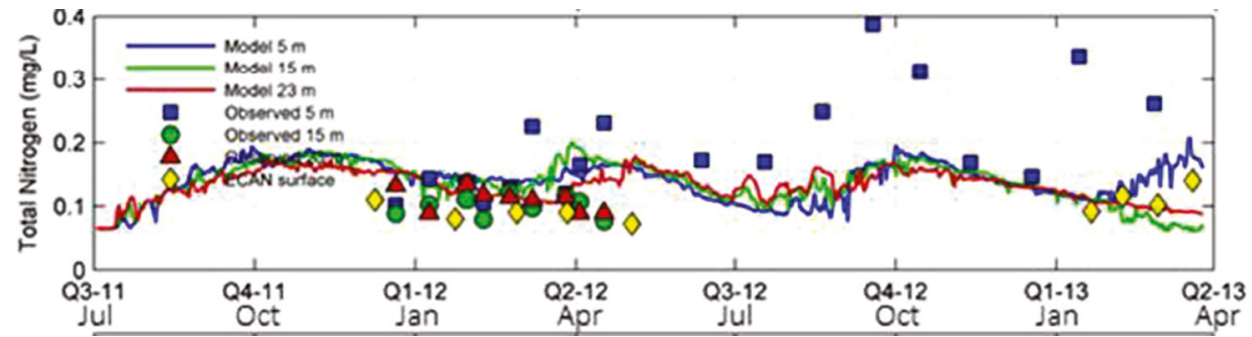

Figure 4b: Results from July 2011 to April 2013.

Figure 4: Simulated (lines) and observed (dots) values for total nitrogen at three depths in the Ahuriri Arm (Spigel et al. [10]).

The Lake Benmore example shows how the estimated limits on catchment nitrogen loading varied based on available data, thus making it difficult to determine if further land use intensification could be accommodated.

\section{WAINONO LAGOON NUTRIENT ENRICHMENT}

Wainono Lagoon is a coastal lake in South Canterbury. There is an artificial opening to the sea which has allowed greater drainage of the wetlands surrounding the lagoon. The drainage has facilitated clearing for agriculture. Nutrient enrichment from surface runoff and groundwater seepage has led to the lake becoming hypertrophic with high levels of nutrients, turbidity and planktonic algae. The conceptual diagram of how water and nutrients, predominantly nitrate, travel through the tributary catchments of Wainono Lagoon is shown in Fig. 5.

Water quality in the Wainono Lagoon has a TLI of 6.5 and exceeds the goal of achieving a TLI of 6 (Canterbury Water [13]). To achieve this, there was a need to reduce the nitrogen loading in the catchment of the lagoon. A draft nitrogen load limit and allocation framework had been developed to meet a TLI of 6 for the lagoon, involving a $15 \%$ reduction in nitrogen load to maintain current water quality and a $30 \%$ reduction to achieve a TLI of 6 for Wainono Lagoon (Norton [14]). The proposed allocation framework was on the basis of 'grandparenting' - allocation directly related to historical discharges.

However, a group of farmers expressed dissatisfaction with the nitrogen allocation framework in relation to the equitability of the framework for low emitters compared to high emitters because high emitters receive a greater allocation. The concern was not about the need to set catchment load limits to achieve environmental outcomes but the method of allocation (Norton et al. [15]). The Nitrogen Allocation Reference Group (NARG) was formed comprising a variety of farming interests, rūnanga (local Māori) representatives and general community interests. 


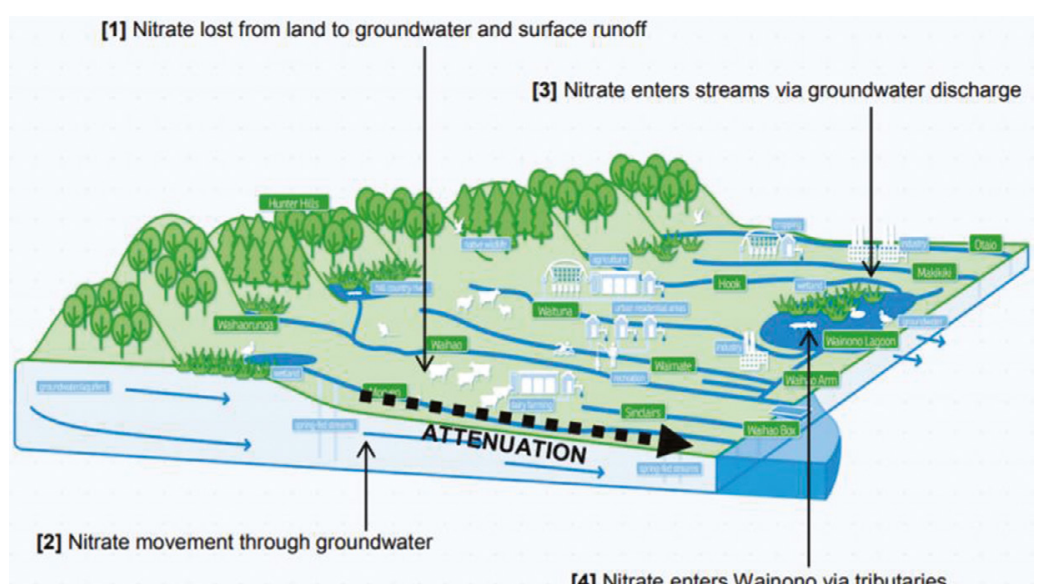

[4] Nitrate enters Wainono via tributaries

Figure 5: Conceptual diagram of water and nitrate flow in tributary catchments of Wainono Lagoon (Norton and Robson [12]).

Note to Fig.5: Nitrate is lost from land to groundwater (1), travels with groundwater (2) and is discharged to spring-fed streams and the lower reaches of hill-fed rivers (3), which are tributaries of Wainono Lagoon (4). Nitrate is attenuated along the way due to a variety of processes including denitrification in anoxic groundwater and soil, uptake by riparian vegetation and uptake by periphyton and macrophytes in streams and rivers

Grandparenting of current discharges was rejected. NARG proposed a requirement for all land users to achieve a minimum of Good Management Practice with respect to nutrient discharges so that poor performers were not rewarded with high nitrogen allocations. The main area of negotiation was the need to create headroom from improved management by high emitters to enable flexibility for nitrogen load increases by low emitters. 'Maximum caps' were to be placed on high emitters according to soil type ( $35 \mathrm{~kg} / \mathrm{ha} / \mathrm{y}$ for light soils, $25 \mathrm{~kg}$ / ha/y for medium soils and $20 \mathrm{~kg} / \mathrm{ha} / \mathrm{y}$ for poorly drained soils) and that they be given a time period to adjust. 'Flexibility caps' were set for low emitters. Initially, these would be set at $10 \mathrm{~kg} / \mathrm{ha} / \mathrm{y}$ (excluding steep hill country farmers who would be assigned $5 \mathrm{~kg} / \mathrm{ha} / \mathrm{y}$ ) (Norton et al. [16]).

The agreement by the NARG was accepted by the Zone Committee, the regional council and the two district councils (Waimate and Waitaki) related to the South Canterbury Zone. The agreement was incorporated in the proposed plan change to the Land and Water Regional Plan (Environment Canterbury [17]).

However, since the preparation of the proposed plan change, there has been a revision of Overseer (the model used to estimate nitrogen loss rates for farms), adjustments to the leaching rates from the Look-Up Tables (the basis for estimating nitrogen leaching rates from farms with different soil types), concerns about the assumptions about denitrification in poorly drained soils and revisions to soil mapping in the Wainono Lagoon catchment. The changes are likely to affect the calculations of catchment loads and maximum caps and thereby the flexibility caps. Interested submitters on the plan change were asked to caucus on the implications of these changes (Whiting et al. [18]). While there is agreement that the changes need to be addressed, the discussions reignited the debate about the appropriate nitrogen allocation methodology and the fairness of the allocations (Environment Canterbury [19]). 


\section{MANAGEMENT OF THE SALINISATION OF THE WOOLSTON-HEATHCOTE GROUNDWATER SUPPLY}

The Woolston Industrial Area is on land on the southern margins of the Avon Heathcote Ihutai Estuary in Christchurch. In the Woolston Industrial Area, groundwater is used for industry and public water supply. Increasing withdrawals led to salinisation of groundwater quality despite the upper aquifer being 2-4 m above sea level and the freshwater/saltwater interface being $3 \mathrm{~km}$ offshore. Investigations indicated that the high salt levels were characteristic of seawater. Furthermore, the saltwater intrusion was not due to the landward shift in the freshwater/saltwater interface. Rather, the elevated salinity was due to estuarine water leaking through the confining layer. This is because the cumulative effects of groundwater pumping in the Woolston area had locally lowered the potentiometric head in the aquifer below sea level in the estuary (Fig. 6).

The factors identified that determined the amount and speed of saltwater intrusion were (1) the thickness and conductivity of the confining layers, (2) the difference between the groundwater level and sea level in the estuary, (3) the length of time over which the difference occurs (e.g. just at high tide or over the full tidal cycle) and (4) the extent of the area affected by downward hydraulic gradient and the proximity to saltwater (i.e. distance from the estuary) (Hertel [20]).

A Water User Group was formed involving all groundwater abstractors. A policy was agreed to ensure an upward pressure gradient (i.e. for the groundwater level to be greater than sea level in the estuary). The following trigger levels were set:

- a moving 365-day average of $1 \mathrm{~m}$ above sea level datum,

- a moving 14-day mean of $0.25 \mathrm{~m}$ above sea level datum and

- a 24-hour average of no more than $0.5 \mathrm{~m}$ below sea level datum.

With the introduction of this policy, bore levels stopped falling, stabilised and then began to recover. After rising over 5 years from an average around sea level to about $1.5 \mathrm{~m}$ above sea level, the groundwater levels stabilised at about $2.0 \mathrm{~m}$ above sea level (Fig. 7). However, salt

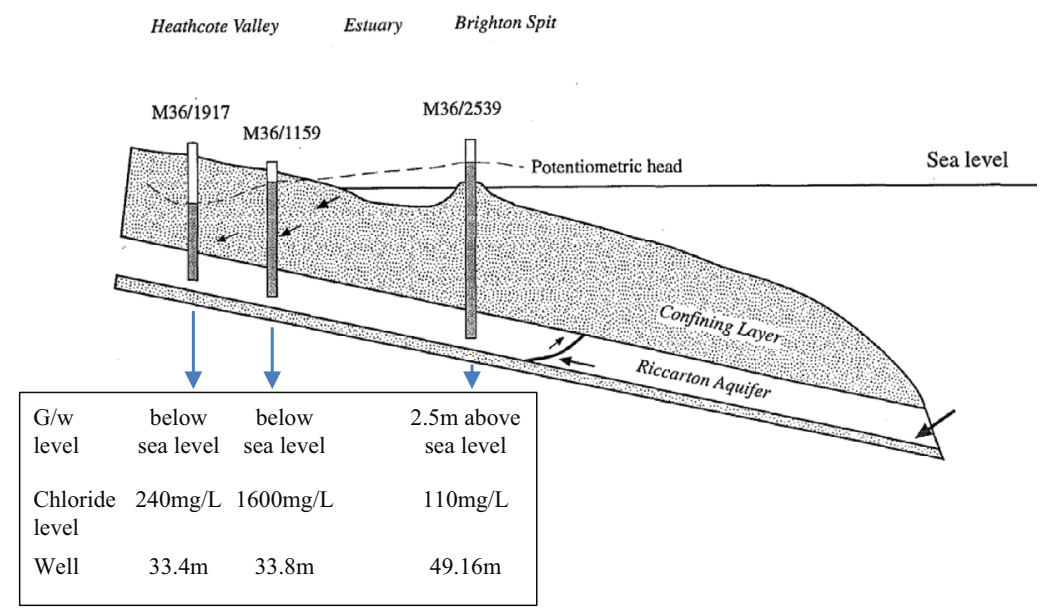

Figure 6: Cross section of downward seepage of sea water into the Woolston/Heathcote Groundwater (Hertel, [20]). 


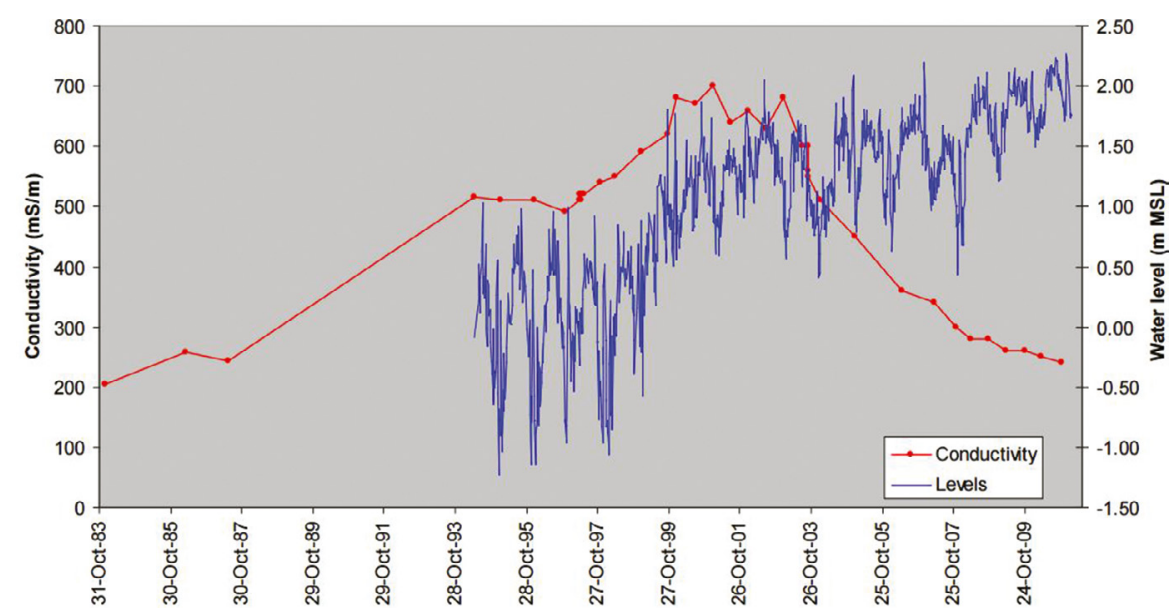

Figure 7: Recovery of bore levels and conductivity in Woolston/Heathcote Groundwater (Scott and Wilson, [21]).

levels continued to rise for a further five years - rising from 500 to $700 \mathrm{mS} / \mathrm{m}$ before dropping over the following ten years to around $200 \mathrm{mS} / \mathrm{m}$ (Scott and Wilson, [21]).

The example shows that cumulative impacts can be managed by all users accepting controls over resource use. When one of the triggers is reached, the allowable consented take is reduced by a third. When two triggers are reached, then the allowable consented take is reduced by two thirds. When all three trigger levels are reached, then all takes must cease. There is also a provision in the policy for a water sharing agreement among all users to provide flexibility among multiple users. The restrictions then apply to the combined takes of all users rather than to each user.

\section{MONITORING OF CONTRIBUTIONS TO CUMULATIVE EFFECTS IN THE TE NGAWAI CATCHMENT}

The Te Ngawai River has a small catchment and has variable flow. Consents for irrigation takes from the river and hydraulically connected groundwater were managed by the river flow at Cave. During the irrigation season (1 October to 30 April), when the river flow at Cave was greater than 500 litres per second, then irrigators could take their full allocation. Between 400 and 500 litres per second, irrigators could take $50 \%$ of their allocated volume. When the flow was below 400 litres per second (the minimum flow allowed for irrigation to be able to occur), then all takes were on restriction. During the irrigation season, the natural river flow would decline, dropping below the full allocation flow and then the minimum flow. Irrigators were partially or fully restricted during most irrigation seasons (Glubb and Miller [22]).

The consents were designed to be managed as a group (the Tengawai Water Users Group); not only were the rates at which individual irrigators can pump specified, but also the combined rates of take were limited when water restrictions are in place. The consent conditions required the group to install measurement, data logging and telemetry equipment. The regional council installed telemetric data transfer equipment as a trial, not only to enable compliance with consent conditions to be monitored but also to facilitate collective management of water takes by irrigators. The telemetry system was linked to the Internet to enable active management and sharing of allocated rates of take and volumes of water. 
Measurements were made of the instantaneous surface water takes, river flow measurements, as well as climate station records and soil moisture probes. A number of management triggers were incorporated so that water users and the regional council were informed when (1) river flows reached restricted levels, (2) an individual user's rate of take was exceeded, (3) an individual user's daily or weekly volume limit was exceeded or (4) the combined rate of take of all users was exceeded.

The key outcomes of the trial were that the data allowed farmers to manage water use and demonstrate compliance. In particular, the data allowed the water user group to share available water during times of restriction. Access to real-time data enabled farmers to actively manage irrigation to maintain productivity while not taking so much water from the river to reduce the flow below the level of full restriction. Use was also made of climate and soil moisture data to facilitate water use efficiency.

The trial demonstrated the significant data management system needed to enable the management of cumulative effects of a group of irrigators. The real-time measurement of individual takes and river flows, the telemetering of data and establishment of the website required a complex system and the design of new technology to make it functional. Also, effectiveness of the system was affected by the slow Internet connection speed in rural areas.

\section{SUMMARY OF LESSONS FOR MANAGEMENT OF CUMULATIVE IMPACTS}

The case studies highlight the following lessons for the management of cumulative effects of multiple projects compared to managing impacts of individual projects.

(1) The spatial scale of management needs to cover all users: in the case of Rakaia-Selwyn groundwater, the spatial scale was the entire groundwater zone and downstream rivers and lake. Whereas for individual projects, the spatial scale is limited to the areal extent of projects impacts: the groundwater drawdown zone of bore extraction in the RakaiaSelwyn groundwater example. It requires managing critical variables, i.e. groundwater level in this case, over the entire groundwater basin rather than just the drawdown at adjacent bores.

(2) The analysis of cumulative effects requires modelling at the regional scale in advance of further individual project proposals, as in the case of nitrate contamination of the Canterbury Plains. The analysis is relevant not only to future project proposals but also to existing users whose projects are already approved. Additional constraints on existing users can be required as well as providing the context for determining whether new projects are acceptable, and if acceptable, the conditions that need to be provided.

(3) The modelling of cumulative impacts is more complex than modelling for impacts of individual projects. Furthermore, the uncertainties in setting limits based on cumulative impact modelling can often exceed the impact contribution of individual projects. The Lake Benmore example demonstrates the difficulties due to modelling uncertainties as well as model calibration and verification in setting sustainability limits and determining whether further development can be accommodated.

(4) The setting of limits to manage cumulative effects has to be translated into allowable contributions among users. As shown in the Wainono Lagoon example, there are equity considerations as to how these allowable contributions are allocated. The issue relates not only to equity in allocation among existing users but also between existing users and potential new users.

(5) In the managing of cumulative impacts, there is a need to manage the aggregate of all contributions as well as the contributions for individual users. In the case of the sa- 
linisation of the Woolston-Heathcote groundwater system, restrictions based on trigger values for groundwater levels were applied to individual withdrawals. However, provisions were also made to allow water sharing agreements between users with restrictions applied to combined withdrawals.

(6) In the monitoring requirements for the management of cumulative effects, there is a need to consider the aggregated contributions and effects of all users. For the flows in the Te Ngawai River, there was a need to integrate the monitoring of individual withdrawals from the river to determine the total withdrawals from the river and to compare this in real time with the instantaneous flow in the river. This facilitated the comparison of total withdrawals with the capacity of the river to accommodate that level of abstraction or whether restrictions on abstractions would need to be applied.

\section{REFERENCES}

[1] Jenkins, B., Challenges in Cumulative Impact Assessment: Case Studies from Canterbury, New Zealand. Environmental Impact IV, WIT Transactions on Ecology and the Environment. Vol. 215, WITPress: Southampton, pp. 25-36, 2018. ISBN 978-1-78466-281-3.

[2] Environment Canterbury, Canterbury Land and Water Regional Plan December 2015. Environment Canterbury: Christchurch, 2015.

[3] Scott, D., Groundwater allocation limits: land-based recharge estimates. Report U04/97, Environment Canterbury: Christchurch, 2004.

[4] Environment Canterbury, Decision of the Commissioners regarding 69 groundwater takes in the Rakaia-Selwyn Groundwater Allocation Zone. Environment Canterbury: Christchurch, 2007.

[5] Bidwell, V., Lilburne, L., Thorley, M. \& Scott, D., Nitrate discharge to groundwater from agricultural land use: an initial assessment for the Canterbury Plains. Prepared for Steering Group of the CWMS, Environment Canterbury: Christchurch, 2009.

[6] Environment Canterbury, Annual Groundwater Quality Survey 2012. Environment Canterbury: Christchurch, 2012.

[7] Foundation for Arable Research (FAR), New Zealand Pork, DairyNZ, Beef+Lamb New Zealand, Horticulture New Zealand, Deer Industry New Zealand, Industry-agreed Good Management Practices relating to water quality. Environment Canterbury: Christchurch, 2015.

[8] Jenkins, B., Water Management in New Zealand's Canterbury Region: A Sustainability Framework. Global Issues in Water Policy Vol. 19, Springer: Dordrecht, 2018. DOI: 10.1007/978-94-024-1213-0.

[9] Norton, N., Spigel, B., Sutherland, D., Trolle, D. \& Plew, D., Lake Benmore Water Quality: a modelling method to assist with assessments of nutrient loadings. Report R09/70 prepared by NIWA for Environment Canterbury: Christchurch, 2009.

[10] Spigel, B., Plew, D., Hamilton, D., Sutherland, D. \& Howard-Williams, C., Updated model assessment of the effects of increased loads into Lake Benmore. NIWA: Christchurch, 2015.

[11] Robson, B. \& Hamilton, D., Three-dimensional modelling in the Swan Estuary, Western Australia. Ecological Modelling, 174, pp. 203-222, 2004.

[12] Norton, N. \& Robson, M., South Canterbury Coastal Streams (SCCS) limit setting process - predicting consequences of future scenarios: Overview Report, Report R15/29, Environment Canterbury: Christchurch, 2015. 
[13] Canterbury Water, South Coastal Canterbury ZIP Addendum. Environment Canterbury: Christchurch, 2014.

[14] Norton, N., Revised Working Draft Nitrogen Load Limit and Allocation Framework. Environment Canterbury: Christchurch, 2013.

[15] Norton, N., Harris, S., Scott, M., Lilburne, L., Robson, M., Stapleton, J., MacDonald, M., Newman, N. \& Whitehouse, W., Process and outcomes of the Nitrogen Allocation Reference Group (NARG) for the South Canterbury Coastal Streams area. Report R14/110, Environment Canterbury: Christchurch, 2014.

[16] Norton, N., Harris, S., Scott, M., Lilburne, L., Robson, M., Stapleton, J., MacDonald, M., Newman, N. \& Whitehouse, W., Process and outcomes of the Nitrogen Allocation Reference Group (NARG) for the South Canterbury Coastal Streams area. R14/110, Environment Canterbury: Christchurch, 2014.

[17] Environment Canterbury, Proposed Variation 3 to the Proposed Canterbury Land and Water Regional Plan. Environment Canterbury: Christchurch, 2015.

[18] Whiting, G., Ellison, E. \& Fenemor, A., Minute 2 (Minute and directions on expert caucusing): proposed Plan Change 3 (South Canterbury Coastal Streams). Canterbury Regional Council: Christchurch, 2015.

[19] Environment Canterbury, Caucusing statement in relation to Nutrient Management provisions: Plan Change 3 to the partially operative Land and Water Regional Plan. Environment Canterbury: Christchurch, 2015.

[20] Hertel, I., Groundwater contamination in the Heathcote/Woolston area, Christchurch, New Zealand. University of Canterbury: Christchurch, 1998.

[21] Scott, M. \& Wilson, N., Seawater intrusion network review. Environment Canterbury: Christchurch, 2012.

[22] Glubb, R. \& Miller, B., Te Ngawai Water Use Telemetry Project. Report U06/65, Environment Canterbury: Christchurch, 2006. 